\title{
Thai Comparative Theologizing: Material and Methodological Reflections
}

\author{
Kari Storstein Haug
}

\section{Introduction}

The increased attention to the study of Christianity as a worldwide phenomenon has contributed to making visible the diverse ways in which the Christian faith is interpreted and practiced around the world. Further, it has highlighted Christianity's complex interactions and negotiations with different religious and socio-cultural contexts. Given this complexity, and taking into account that the different contexts in which Christianity as a religion finds itself present the researcher with different methodological challenges and opportunities, the question arises as to how knowledge about this field of study could be acquired and/or created. This chapter intends addressing this question by presenting and discussing the case of how Christians in Thailand are interacting with the predominantly Buddhist religious context of the country. It will present and analyze two examples of Thai comparative theologizing. The focus and discussion point will be first, how Thai Christians reflect on their faith in light of and as a response to the religious context in which they are situated, and second, how to create knowledge about this reflective practice and theologizing.

\section{$2 \quad$ Religious Context}

Christianity has an approximately five hundred-years-old history in Thailand, and is diverse in terms of denominational backgrounds and affiliations (Björkgren-Thylin 2009: 44-47; Fleming 2014: 53-59; Keyes 1993). ${ }^{1}$ Despite

1 The history of Christianity in Thailand begins in the mid-sixteenth century through the contact with the Portuguese. The first resident Catholic missionaries were two Portuguese Dominicans, followed by French Catholic missionaries. Protestant missionaries were allowed into the country from 1828 . In contemporary Thailand, the government recognizes five Christian organizations. The Church of Christ in Thailand (сСт), the Evangelical Fellowship of Thailand (ЕғT), the Thailand Baptist Convention (твС), the Seventh-Day Adventist 
Christianity's relatively long presence in the country, Christians constitute a tiny minority in Thai society, a society in which the religious and socio-cultural context is very much formed and informed by Buddhism. At the same time, Thai Christians are embedded in the complex and transnational web of connections and networks that constitutes contemporary World Christianity.

The majority of the population in Thailand is Buddhist (94.6 percent), while Islam is the second largest religion in the country, with 4.3 percent followers. Christians constitute 1.0 percent of the population. The remaining o.1 percent is affiliated with other religions (National Statistical Office). ${ }^{2}$ According to the constitution, the king must be a Buddhist, and is the patron of the Sangha (the monastic community). At the same time, he is the protector of all religions (Ishii 1986). The state supports Buddhism in various ways, and Buddhism is taught in all government schools. It is further considered as one of the three nationally promoted pillars of Thai identity, which are religion, king, and nation (Slagter and Kerbo 2000: 88-89, see Reynolds 2002 for a critical discussion of Thai national identity).

Buddhism in Thailand belongs to the Theravada tradition of Buddhism. ${ }^{3}$ It is multifaceted and can be described in a variety of ways. At the most basic level, it is possible to distinguish between doctrinal Buddhism and popular Buddhism. Doctrinal Buddhism refers to Buddhism as it is taught and practiced based on the Pali scriptural tradition and authoritative commentaries to these (Payutto 2003/2546). Popular Buddhism is Buddhism as it is understood and practiced by the ordinary adherents of the religion — but also many monks and mae-chiis (nuns) - and which differs in emphasis from doctrinal Buddhism (Podhisita 1998/2541; Kitiarsa 2012; Slagter and Kerbo 2000: 78-89; Swearer 1973). This latter type could-with reference to Melford Spiro's wellknown categorization of the soteriological system of Buddhism-be described as karmatic Buddhism, having a focus on gaining a better life in this and next life. In addition, popular Buddhism in Thailand includes a belief in

Church, and the Roman Catholic Church. In addition, there are a great number of unofficial independent churches as well as mission organizations and missionaries coming from different countries and denominations.

2 Five religions are officially recognized, that is, Buddhism, Christianity, Islam, BrahmanismHinduism and Sikhism. These religions are supported and regulated by the state through the Department of Religious Affairs, under the Ministry of Culture. In addition, there is an Office of National Buddhism. This office reports directly to the Prime Minister.

3 According to tradition, missionaries from India introduced Buddhism to the area of what is present day Thailand, in the era of King Ashoka (304-232 BCE). Most scholars agree, however, that is from the era of the Sukhothai kingdom (1238-1438 ACE), that Buddhism was consolidated in Thailand (Phra Dhammapitaka i.e. P.A. Payutto 20o1; cf. also Baker and Phongpaichit 2014). 
the world of spirits and magic, which Spiro describes as apotropaic Buddhism (Spiro 1982: 11-13, 66-161).

\section{$3 \quad$ Research on Christianity in Thailand}

Previous research has demonstrated that Buddhism, particularly popular Buddhism, has decisively formed Christianity in Thailand. Several studies of the Church of Christ in Thailand, for example, argue that the teaching of karma is a framework influencing Christian faith and practice in decisive ways (Hughes 1984, 1985; Suwanbubbha 1994). Nevertheless, research into Christianity in Thailand more generally, has also shown that its understandings of and interactions with Buddhism and Buddhists are quite variegated. It has been influenced by different denominational and theological discourses resulting from its international connections through, for example, missionaries (Fleming 2014).

Looking at the available studies of Christianity in Thailand, especially those which address the interaction between Christianity and Buddhism, it is possible to divide them into the following categories. First, historical studies of Thai church- and mission history, which in different ways give important insights into the history of the encounter between Christianity and Buddhism (see for example Chaiwan 1984; Smith 1999; Swanson 1984). Second, empirical studies of Thai Christians, mainly using qualitative approaches and methods, focusing on how Christian faith and practice has been influenced and formed by its encounter with Thai Buddhism (some examples are Cohen 1995; Haug 2015; Hughes 1985; Suwanbubbha 1994; Zehner 1991, 2005, 2009). Third, empirical studies of conversion and church growth (Galgao 2019; Hilderbrand 2016; Sandland 2014, Visser 2009; Zehner 2013). Fourth, literature on Buddhist-Christian encounter and dialogue in Thailand. As Bantoon Boon-Itt documents in his doctoral study there is a limited amount of studies in this field (Boon-Itt 2007). The studies he mentions will be discussed in the next section. There are some studies focusing on how Christianity is or could be viewed from a Buddhist perspective (Buddhadasa Bhikkhu 1967; Sivaraksa 1986, 2002). A few articles present and discuss interreligious dialogue in Thailand (Phongpit 199o/2533; Ratanakul 2005; Suwanbubbha 1998). A recent book by Kenneth Fleming both gives an overview of some of the history of the Buddhist-Christian encounter in Thailand and presents some contemporary cases (Fleming 2014). ${ }^{4}$ My own study of how to interpret Old Testament

4 Fleming (2002) has also a chapter on the theology of Kosuke Koyama's (a former missionary to Thailand) theology of dialogue with Buddhism. 
wisdom texts in light of Thai Buddhists' interpretations of the same texts addresses the question of interreligious hermeneutic and Bible interpretation in a Buddhist context (Haug 2012). Fifth and finally, there are a few theological and practical-theological oriented studies from a Christian perspective. The majority of this literature is written by non-Thais, predominantly scholars who are, or have worked as, missionaries in Thailand, and is mostly concerned with contextualization issues and/or church growth (for example Davis 1993; Grether 196o; Hong-Shik 1989; Hovemyr 1983; Koyama 1974; Taylor 2005).

\section{4}

\section{Thai Theology}

With some notable exceptions, very few Thai scholars and theologians have discussed or published on the issue of Thai theology. That is, there are not many publications by Thai nationals, engaging in a theological discourse of interpreting Christian faith and practice in dialogue with the historical and contemporary context of Thai society. In the words of church historian Herbert R. Swanson: "Few Asian nations, however, have been as 'silent' theologically as Thailand, and from an international perspective, it would seem fair to wonder if 'Thai theology' ever exists, particularly among Thai Protestants" (Swanson 2002: 59; see also Taylor 2005). Swanson's observation resonates with the conclusion Boon-Itt reached after having searched for theological thinking by Thai Christians on the Buddhist-Christian encounter: "In the past fifty years, research and writings from Thai Christians responding to or relating to Buddhism have been scarce" (Boon-Itt 2007:139). ${ }^{5}$

Most of the available studies written by Thai theologians focus on the question of how to communicate the gospel in Thailand in ways that are culturally appropriate and understandable for Thai Buddhists (Boon-Itt 2007; Lorgunpai 1995; N. Mejudhon 1997; U. Mejudhon 1997; Petchsongkram 1975). Boon-Itt, Lorgunpai and Petchongkram argue that in order to communicate effectively it is necessary to use terms and concepts that Thai Buddhists can understand. ${ }^{6}$ This demands in-depth knowledge of both Buddhist and Christian worldviews and concepts. Lorgunpai further sees the potential of comparing biblical insights with Buddhist teaching. In his doctoral dissertation, he compares the theological content of Ecclesiastes with central themes in Thai Buddhism, pointing out similarities and differences. He concludes that both Thai Christians and

5 Boon-Itt found only seven studies (six are doctoral dissertations) on this issue, of which just two are published. The two published studies are Petchsongkram 1975 and Lertjitlekha 1998.

6 Behind this assertion, one finds both an implicit and explicit critique of the overly westernized ways of formulating and communicating the Christian faith in Thailand. 
Buddhists can benefit from such a comparison: "It [Ecclesiastes] provides Thai Christians with a tool for communicating with Thai Buddhists. Likewise, Thai Buddhists will realize that some messages in the Christian Bible are not entirely foreign to them. They can also gain some insights from reading Ecclesiastes and will have an alternative response to human suffering" (Lorgunpai 1995: 270-271, see also Lorgunpai 1994). Like Lorgunpai, Lertjitlekha also has a comparative approach. He compares Buddhist and Christian ethics, and argues for the importance of dialogue in this matter. In his opinion, dialogue contributes to "moral progress and mutual understanding of each partner. This in turn brings self-understanding and self-correction of each one in their own faith" (Lertjitlekha 1998: 383). He also stresses the importance of understanding the two religions on their own terms and highlighting their uniqueness. Nantachai and Ubolwan Mejudhon are particularly concerned with finding culturally appropriate ways of communicating the gospel, and argue that there is much to be learned from Thai culture (and by extension Thai Buddhism) in the way it emphasizes the value and attitude of meekness. Finally, Phongpit makes a strong case for dialogue and its importance for theological understanding. According to Boon-Itt, ${ }^{7}$ he argues that "one's own understanding of one's own religion is only made whole when 'one finds out that it is no longer possible to comprehend one's own religion without considering the reality of the other religions'" (Phongpit in Boon-Itt 2007: 143).

While the relatively limited amount of studies by Thai theologians might lend some support to the conclusion that Thai theology seems to be rather underdeveloped, it could, however, be argued that the way Thai Christians live and interpret their lives in light of their faith is an expression of everyday theology (Vanhoozer, Anderson and Sleasman 2007). As we have already noted, previous research into the encounter between Christianity and Buddhism in Thailand has argued that the faith and practice of Thai Christians has been decisively informed and shaped by Thai Buddhism. Little attention has been paid, however, first, as to how Thai Christians' faith and practice could be interpreted as

7 Boon-Itt refers to Phongpit's doctoral thesis, which is unpublished (Phongpit 1978). Unfortunately, I have not been able to get hold of the thesis, so I rely on Boon-Itt for this reference. 
an expression of Thai everyday theology and theologizing, and second, to the question of the agency of Thai Christians in this process. ${ }^{8}$

How to study and get hold of Thai theologizing efforts? One approach, which is found in Swanson's article 'Dancing to the Temple, Dancing to the Church' (Swanson 2002), is to observe and reflect on, from an everyday theology perspective, how ordinary Thai Christians live and negotiate life and practice in their daily encounters with Buddhist neighbors and their religious rituals and practices. Fleming also utilizes an empirical approach in a similar, but more general, case study of a village, which includes both a Buddhist and Christian community (Fleming 2014: 119-139). Their approach reflects a turn, both in theology and religious studies, to more empirical studies of religion. In these studies, the focus is on religious faith and practices as they are understood and lived out by different kinds of practitioners, not at least so-called ordinary believers (Ammerman 2007, 2014; Tanner 1997; Wigg-Stevenson 2014). I think Swanson's and Fleming's contributions - even though they are limited in scope-demonstrate that this approach might contribute valuable material to the understanding of how Thai Christians actively interact and negotiate with their context. More research however is definitely needed in this area. Hence, I concur with Clarke, who contends that "... the field of world Christianity needs to deliberately embrace the messiness of the lived forms of Christianity that take root and bear fruit in historical contexts of diverse peoples and disparate places on our earth" (Clarke 2014: 195).

The approach I will develop and discuss here, however, takes comparative theology as its point of departure, but argues that by developing this approach in a more empirical direction, it has the potential of expanding our knowledge of the complex interactions and negotiations in which Christianity as a world religion is embedded and involved.

Comparative theology aims at exploring how the wisdom of other religions might enrich one's own faith and belief. The comparative theologian does a careful study of, and attentive listening to the ideas of other religions, and then proceeds to ask how these insights could contribute to the interpretation and understanding of Christian faith and theology (Clooney 2010a, b). In my opinion, comparative theology in the tradition of Francis Clooney has contributed valuable insights and reflections on the interreligious encounter (Clooney 2005, Fredericks 2004). For a useful review of newer developments and discussions, see Heim 2019). The approach has however, according to my knowledge,

8 One exception here is Zehner's study into Thai Christian interactions and negotiations with Thai animistic beliefs (see for example Zehner 2005). 
mainly been used by western Christian academic theologians, ${ }^{9}$ and have not been applied to ethnographic empirical material or to ordinary people's reflection on their faith. Based on my own research and fieldwork in Thailand, I would like to argue that a focus on comparative theology in the creation and analysis of empirical material yields fruitful insights into Christianity in Thailand. ${ }^{10}$ In the following, I will present what I label as two examples of comparative theologizing based on Thai Christian and Buddhist readings of two biblical wisdom texts. My question is if one by approaching the study of Christianity in Thailand with a focus on empirical comparative theology could learn more about how Thai Christians engage and negotiate their faith in dialogue with the predominantly Buddhist context in which they find themselves.

Case Study: Thai Comparative Bible Reading and Theologizing

In the following, I will first present an example of how comparing Thai Buddhists' and Christians' interpretations of two Biblical wisdom texts can contribute to understanding how Thai Christians negotiate their faith and theology in a context highly informed by Thai Buddhism. Second, I will give an example of Thai comparative theologizing by highlighting some Thai Christians' reflections on the teaching of karma.

The material referred to in this section was created during fieldwork in Bangkok, Thailand in 2005. I invited nineteen Thai Buddhists and thirteen Thai Christians to read and interpret three texts from the Old Testament wisdom literature (Proverbs 11: 18-31, Psalm 73 and Ecclesiastes 9:1-12). ${ }^{11}$ The Thai readers included both religious specialists and ordinary believers, men and women, young and old, educated and uneducated. After having had an initial contact on mail or on phone, I usually met the respondents twice. The first time I met them, I informed them in more detail about the research project and agreed on where and when we would meet for an interview. In addition, I gave them a copy of the three Bible texts that I would like to discuss with them, in order for them to have the opportunity to read the texts in advance. The second time

9 There are some exceptions, see for example Tatari 2017.

10 A similar methodological consideration is made by O'Donnell 2017.

11 The three biblical texts belong to the wisdom literature of the Old Testament. All three texts discuss in some way or other the relation between act and consequence, a central topic in the wisdom literature. See Haug 2012:12-14 regarding the rationale of choosing these particular texts. In this chapter, I focus on the Thai readings of Proverb 11:18-31 and Psalm 73. In the Proverbs text there is a clear expectation about order or justice in life (an optimistic view of causation), while the Psalm questions this way of thinking. 
we met, I conducted the interview, where the focus was on how the respondents read and understood the texts and their topics. The interviews had an exploratory aim and were semi-structured (Rapley 2004). I interviewed the respondents individually, with one exception: Two of the Buddhist monks wanted to be interviewed together, as they were not comfortable being interviewed by a woman alone. A typical interview lasted one to one and a half hour. All interviews were conducted in Thai. ${ }^{12}$

Thai Interpretations of Proverbs 11:18-31 and Psalms 73

\subsection{Main Themes}

Both the Buddhist and Christian respondents argued that the overarching theme in Proverbs 11: $18-31$ is the relation between act and consequence. In their interpretation of the text, most of the respondents referred to the wellknown Thai saying, "do good, receive good; do evil, receive evil", and argued that this saying could very well sum up the main teaching of the passage. One of the respondents, Dr. Phimpan, formulated it as follows: "It is about [...] 'do good, receive good; do evil, receive evil' [...] every verse can be summarizedthey all mean the same-as: If one does good, then in return one will receive that which is good". In other words, both groups of respondents emphasized that the text stresses the correlation between act and consequence, and read the different verses as exemplifications and further explications of this.

Next, both the Buddhist and Christian readers claimed that the text thematizes how to understand the connection between act and consequence, and they agreed that in the text, the answer to this question somehow relates to the issue of how to understand God and God's role. Nevertheless, as we will see below, views differed as to how God's role should be understood in more detail. Finally, yet importantly, both groups of respondents read the text as an address to the reader, calling upon its readers to live ethically good lives, and avoid acting unjustly. ${ }^{13}$

Even though the Buddhist and Christian readers largely highlighted the same main themes in the Proverbs text, there are some differences in emphasis. For example, the Buddhist readers mentioned two themes, which the Christian

12 I have studied Thai language, and worked in Thailand for eight years over a ten years period (1994-2003). I have translated all quotations from respondents from the Thai original transcript.

13 "Whether [the results of acts] are the result of karma in Buddhism or, like one expresses it in Christianity, [due to the fact that] God gives, what is for sure [is that this text] encourages people to do good" (Phra Suthep and Phra Phongsak). 
readers did not mention at all. First, several of the Thai Buddhist respondents argued that the text strongly emphasizes that there is no way to escape the consequences of one's actions. Second, some of the Buddhist respondents found the text to highlight the theme of human freedom. That is, the freedom of human beings to control their own destiny. Even though some of the Christian informants emphasized that the text makes clear that there are different paths of life to choose between, and indirectly challenges the reader to make a choice, none of them claimed that the text should be interpreted as meaning that the destiny of an individual is in his or her own hands.

Reflecting on Psalm 73, all the respondents agreed that the psalm raises a basic question, which challenges the idea of correspondence between act and consequence put forward in Proverbs 11. The question is why the good suffers, while the wicked seems to be successful and prosper, or as Mr. Wibun puts it: "Why [is it that] the evil, the more evil they do, and the richer they get? S/he [the psalmist] does that which is righteous, but why does s/he end up having nothing good?" The respondents further argued that this is a common human experience and most of them also pointed to a Thai play of words on the saying referred to above (do good, receive good, do evil, receive evil), namely: "Do good, receive good, where do we find that? Do evil, receive good, this is found everywhere!"

The psalm was read as a person's existential struggle with this problem, and particularly as the psalmist's struggle understanding his/her own situation in the light of his/her faith in a good and just God. All the respondents believed that the psalm offers an answer to the psalmist's problem, but they differed in their interpretation of it (more on this below). In addition to pointing out the main theme and question of the psalm, all the respondents became very engaged by the psalmist's lament. They both suggested how it could be understood, and evaluated the psalmist and his response to the situation. The respondents agreed that the formulations in the first half of the psalm should be seen as an expression of the psalmist's strong emotional reaction to his/her situation, being in despair and heavily depressed. Nevertheless, they disagreed in their evaluation of the psalmist's reaction. Most of the Buddhist respondents were very critical of the psalmist's lamentation and interpreted it as an expression of ignorance and lack of faith. ${ }^{14}$ The background for this assessment is the Buddhist teaching that when a person grows in wisdom and insight, s/he

14 "This, if [I am to] put it bluntly, is foolishness, ignorance, because if $\mathrm{s} / \mathrm{he}$ [the psalmist] knew, had wisdom, he would not have been jealous; s/he would have known that this group [the wicked] will not [receive] good for very long. Soon their karma will catch up [with them]" (Dr. Somsri). 
will understand the cause of the suffering and the apparent incoherence between deeds and consequences. Consequently, the reason for the lament will disappear. Similarly, some of the Christians respondents also believed that the psalmist's lament was founded on wrong understandings. Nevertheless, compared to the Buddhist respondents, most of the Christian readers were much more positive in their assessment of the psalmist. Even though they agreed that he used very strong language, they believed that it is legitimate to come to God with the feelings and questions you have. Differences in the perception of God and God's role seem to be the main reason for the different interpretations (see below).

In summary, when looking at what kind of themes the respondents find in the texts, it is, despite some differences, the similarities that dominate when comparing the Buddhist and Christian readings. However, when I analyze how these topics are understood in more depth, and look into the rationale behind the interpretations, the picture becomes a bit more complex. In the following, I will point to some of the similarities and differences in how the Christian and Buddhist respondents developed and explained the themes in more detail.

\subsection{The Understanding of the Themes}

Reading the Proverbs text, both Buddhists and Christians suggested that this text is about the correspondence between deed and consequence and that God in some way or another is related to this. How is the role of God understood among the respondents, and what, if any, are the similarities and differences between Christian and Buddhist interpretations?

Many of the respondents, both Buddhists and Christians, believe that the relationship between act and consequence is a law of nature that applies to all people. Accordingly, the Buddhist respondents argue that what the text does is that it describes the law of karma. The majority of Christian readers, on the other hand, does not use this terminology, but rather speaks in general terms about a law of nature arising from the fall. Some of them named this as "the law of righteousness and injustice", based on the argument that there seems to be an in-built law in nature ensuring a just retribution of good and bad acts.

When it comes to the question of the role of God in the relationship between act and consequence, one group of Buddhist respondents argued that God could be compared to the law of karma. God does not have an independent role in the act-consequence process. God's function is only to facilitate the process and ensure that the seed is bearing fruit. While some of the Christian respondents thought it could be argued that God uses the law of karma or the natural law of correlation between act and consequence, none of them would say that God only facilitates a natural process. The reason was that they 
believe that God has the power to overrule this law. In other words, several of the Christian respondents believed that God could be said to fulfil the same function as the law of karma and repay persons righteously in accordance with their deeds. At the same time, they emphasized that God is not a law of nature, but a person, and therefore $\mathrm{s} / \mathrm{he}$ can choose to forgive people their iniquities, and be gracious to them.

Another group of Buddhist respondents interpreted the role of God in the act and consequence nexus differently from the first group. They argued that in the text God seems to replace the law of karma, in the sense that it is God, who assigns the result of a person's actions. God can therefore be described as a judge rather than a facilitator. This interpretation largely corresponds to how many of the Christian respondents interpreted the text. Both these two groups of respondents emphasized that such an interpretation of the text implies an understanding that the outcome of human action does not depend solely on one's own, but that it depends on someone outside of himself or herself. While the Christians perceived this as positive, the Buddhists perceived it negatively. They believed that this creates a basic insecurity with regard to what one can expect because of one's deeds. The Christian readers, however, found the idea of God's free agency as hopeful and comforting. Even if a person had not managed to live the way s/he should, s/he could still hope and believe that God would show mercy and forgive.

Returning to the two themes that some of the Buddhist respondents highlighted, but which are not mentioned by any of the Christians (one, the impossibility to escape the consequences of one's actions; two, everyone is responsible for his own destiny), it appears that the Buddhist respondents who emphasized these two themes were the same who believed that in this text, God and the law of karma must be understood as the expression of the same reality. The fact that the Christian readers do not mention these topics could thus be understood as an expression of differences in the interpretative framework of the Christian and Buddhist readers.

Reading Psalm 73, all respondents found it to address the question of how to understand the fact that human experience seems to problematize the expected correspondence between act and consequence. How they explained the reasons for the problem of the psalmist, evaluated his lament and understood the solution of the psalm, were very much dependent on the wider hermeneutical framework in which they read the text.

As regards the Buddhist readers' explanations, these were largely characterized by a common Thai Buddhist understanding of karma. Both suffering and happiness are a result of karma. The discrepancy between act and consequence 
can be explained in terms of so-called old $k a r m a,{ }^{15}$ or it could be an expression of the psalmist not being as good as $\mathrm{s} /$ he believe. The correct attitude in face of suffering should be to continue doing good, trusting that the law of karma is utterly just. Many of the respondents accordingly interpret the lament as spiritual immaturity and ignorance. The Thai Christians, however, did not seem to think that suffering is the result of ignorance or sin, or that good deeds are the way one gets rid of pain and suffering.

As we have seen above, there is a fundamental difference between the Christian and the Buddhist readers in how they understand God, and this difference influences the interpretations of Psalm 73 as well. Despite the fact that the righteous suffer and the wicked prosper, the Christian readers believe that God is in control and that God might both send suffering (for example in order to test or to discipline) and turn suffering into something good. They maintain that God is both righteous and good and trust that s/he has a good plan and purpose with everything that happens. Whereas many of the Buddhist readers argue that believing in God as a personal actor creates insecurity because one does not know what one has to deal with; the Christians are comforted by the thought of God being in control, because they are convinced that God wants them well. This difference in the understanding of God also appears to be the main reason in the different way the majority of the Buddhist and Christian readers evaluate the psalmist's lamentation. For the Christians, God is not an impersonal principle, but is regarded as a person who cares for them. As one of the respondents formulated it: "God can be compared to a father, friend, or mother." In such a close relationship, it is possible to share what is on your heart.

Further, differences in interpretative framework also influence the understanding of what kind of solution the psalm offers to the problem it articulates. Both the Thai Christian and the Thai Buddhist respondents found that the psalmist received an answer to his/her question. Based on their reading, they agreed that the psalmist realizes that everyone will be rewarded in accordance with their deeds. While for most of the Buddhist readers this was seen to be the final answer, the Christian readers were of the opinion that the most important insight was that God is always present, no matter the situation. God is rendered fair, but at the same time as one who takes care of those who turn to Godself.

\footnotetext{
15 'Old karma' is often explained as bad karma that one has previously committed, either earlier in this life, but even more often in a previous existence.
} 


\subsection{Thai Christian Discourses on Karma}

Based on the Thai Buddhist and Christian readings of Proverbs 11 and Psalm 73, I will now turn to the question of how the Thai Christians explicitly reflected on the question of karma in relation to their own Christian faith and beliefs. How did the Christian Thais, who were interviewed, theologize in dialogue with the karma framework?

As we have seen above, the teachings of karma constitute the basic framework for the Thai Buddhist interpretations of the texts. It served as an interpretive key to pinpoint and interpret the themes of the texts, as well as pointing out similarities and differences between Christianity and Buddhism. Contrastively, none of the Thai Christian respondents explicitly used the concept of karma or 'the law of karma' in their interpretation of the texts, even though they referred to this way of thinking more implicitly. This is in line with findings in previous research, for example Hughes' findings in his study of the Church of Christ in Thailand (Hughes 1982). Interested in how the Thai Christian respondents would reflect on their interpretation more explicitly in light of the karma teaching, I asked them, towards the very end of the interviews, to reflect on what they had said about the texts and their themes in this light. Here follows a brief summary of their reflections.

One issue raised by many of the respondents, was whether the acts described in the texts could be denoted as karmic acts. Several of the respondents underlined that if karma is understood as action, and the law of karma as that which governs the relationship between act and consequence, this text could be said to deal with karma and the law of karma. "It is the law of karma, I think it is the same, see for example verse 31 [Proverbs 11]. This means that if someone who does good is oppressed in this world, those who did it will be punished more than this in the next world. This, I think, is the law of karma" (Mr. Suchart).

At the same time, the same respondents pointed out that Christians do not believe in rebirth. Therefore, they do not think of karma in the same way as the Buddhists. Connected with this point, some of the respondents emphasized that as Christian one has no karma, in the sense of being guilty of sin, because of Jesus' redemptive work. "Jesus has redeemed it (karma) already. Therefore, karma or the circle of rebirth has no power in my life now. When I die, I don't have to use my karma in hell, or be born again to use up my karma" (Mr. Paisan).

When it comes to the question of how God and the law of karma relate to each other, none of the respondents thought that God or the law of karma is an expression of the same reality. The main argument against comparing God with the law of karma was that the latter is considered as a law of nature, while 
God is a person. "A law of nature is a thing, it doesn't have life. It is a thing that cannot show mercy. In fact, if it is a law of nature, there are no exceptions, isn't it so. If I do karma, bad karma, I have to receive the bad karma. A law of nature cannot be merciful or forgive, but our God has mercy with us. So there is a difference, God is a person, not a force of nature" (Mr. Somsak).

In other words, the respondents argued that there is a main difference between the law of karma and God. As a law of nature, the law of karma cannot show mercy, love or forgive. God, however, as a person, can do all these things.

Even though all the Christian respondents emphasized that God and the law of karma are not the same, some of them argued that the law of karma is a tool used by God. "The law of karma is not God, but it is a tool, which God uses. When humankind fell in sin, it emerged, that is, the law of karma originated. It is a restrictive measurement, which God established, namely that everyone needs to reap the fruit of their own doings" (Mr. Suchart).

Here it is stressed that the law of karma originated because of the fall. A couple of the respondents were also careful to emphasize that God did not create the law of karma. It originated because of human disobedience to God. "God did not create the law of karma, but the result of karma originated when humankind fell in sin" (Rev Anuman).

In the previous section, we have seen that several of the Christian respondents argue that act and consequence naturally hang together. There is a natural connection between act and consequence. God blesses those who do good and punishes (with a loving, disciplining purpose) those who do bad. Here, therefore, one can find support for the claim that Thai Christians interpret their faith within a karmic frame of reference. Several of the Thai Christians also argue that on certain conditions, one could also use the language of karma to describe Christian theological insights. Nevertheless, in two central areas, the Christian respondents' theologizing breaks with an interpretation based on the law of karma. None of them has a cyclical understanding of reality. This means that the relationship between act and consequence is not interpreted as expressing the law of karma, to the extent that the law of karma is understood as the law governing the rebirth process. Further, none of the Christian respondents thinks of God and the law of karma as referring to the same reality. That is, they do not think of God as a law of nature or an impersonal law that regulates the relation between cause and effect. According to the Christian respondents, God is a personal force, independent of and over the laws of nature. God therefore, has the opportunity to break the chain of causal effect and can, for example, forgive human beings their iniquities and not let them experience the natural consequences of their actions. 
What kinds of knowledge and insights does this case study into Thai reflections on biblical texts and their themes contribute? First, how do Thai Christians reflect on their faith in light of and as a response to the religious context in which they are situated? Second, and in extension, how to create knowledge about this reflective practice and theologizing?

I have presented two types of comparative theological work, which contribute with both material and methodological insights. First, I have analyzed and compared two sets of Thai readings and reflections of Proverbs 11:18-31 and Psalm 73. Second, I have presented examples of Thai Christians comparative theologizing on the theme of karma.

In the first example, the comparisons of Thai Buddhists' and Thai Christians' interpretations of biblical texts highlight and reveal significant similarities and differences in the understanding of, and reflections on the texts. In the analysis, I found similarities and differences both in terms of themes they found in the texts and in terms of the basic framework of understanding that informed how they understood the text. In the second example, it became apparent that the Christian respondents differed as to how they would conceptualize the ideas connected with the law of karma, and to what extent they found it useful to use the term of karma in their reflections. Nevertheless, their reflections on the thinking of karma revealed that the Christian Thais, who I interviewed, were willing and able to create a dialogue between Buddhist thinking and Christian theology.

Comparing the interpretations of the Thai Christians' with the Buddhists' interpretations reveals the complex and rich ways in which the Thai Christians interpreted their beliefs in dialogue with Buddhist faith and understanding of reality. The comparison has given in-depth insights into the main interpretive frameworks activated in the reading of the texts and its themes. Whilst the Buddhist respondents largely interpreted the text in light of the teachings of karma, the Christians' main interpretive key seems to be their understanding of God. The analysis has shown that the Christians' perception of God differs from the Buddhists' perception, and that the Christians' image of God contributes to a new framework for interpretation on their part. This is an interesting finding in my material, as previous research has largely concluded that Christians interpret their beliefs within the framework of a traditional Thai worldview.

The Thai Christians' readings demonstrate that they do not share the worldview underlying the karma thinking, although their thinking and understanding may still be characterized by several of the elements that make up the 
teachings of karma. I would argue that their interpretations could be viewed as a dialogue between different drafts of understanding of reality. The Thai Christians' interpretations demonstrate that they engage in a theological creative process. They do not only exchange the law of karma with God and otherwise preserve their former worldview unchanged, but also reflect on their faith in dialogue with the context in which they find themselves. The new basis for interpreting life, which the Bible provides, as well as the new interpretative context constituted by the Christian community provide the Christian interpreters with new resources and frameworks in their understanding of reality. This again informs their interpretation of individual texts in the Bible. In other words, by comparing readings of the same texts, and engaging Thai Christians in comparative theologizing work, my research demonstrates that insight is gained into the complex and innovative ways in which Thai Christians negotiate their faith in the midst of a majority Buddhist context.

Further, my case study shows that a focus on how Thai Christians themselves reflect and compare their faith and practice to Buddhist understandings and concepts sensitizes and alerts the researcher to the agency of the Thai believers. In the literature describing Christianity in Thailand, there has been a tendency to describe its contextual character in a way that indicate an uncritical and/or unconscious appropriation of Thai Buddhist ideas and worldviews (Hughes 1984; Kusawadee 2010; Taylor 2001), while it could also be interpreted in terms of negotiation, innovation or Thai Christian theologizing.

\section{$9 \quad$ Concluding Remarks}

Studying Christianity as a worldwide phenomenon in all its complexity and diversity requires the use of a variety of methodological approaches. It is thus a necessary and important task to investigate and discuss how to develop and expand the methodological toolbox for creating knowledge about this field of study.

Through a presentation and analysis of a case study from Thailand, this chapter has made an argument for the importance of using empirical studies of lived faith, and sociological and comparative methods in order to unfold and understand the interfaith entanglements of Christianity worldwide. The chapter has argued that using an empirical comparative theological approach in studying the phenomenon of World Christianity can contribute with in-depth knowledge of both the agency of local Christians and local and contextualized forms of Christian theology and practice. I would argue that the case study presented in this chapter demonstrates that applying a 
comparative theology approach to the creation and analysis of empirical material might sensitize and alert the researcher to the constructive theological work being done by local Christians, and contribute with new knowledge of and insights into the rich and multifaceted phenomenon of World Christianity.

\section{Bibliography}

Ammerman, Nancy Tatom, ed. (2007). Everyday Religion. Observing Modern Religious Lives. Oxford: Oxford University Press.

Ammerman, Nancy Tatom (2014). Sacred Stories, Spiritual Tribes. Finding Religion in Everyday Life. Oxford: Oxford University Press.

Baker, Chris, and Pasuk Phongpaichit (2014). A History of Thailand. Cambridge: Cambridge University Press.

Björkgren-Thylin, Marika (2009). From Pioneer Mission to Autonomous Church. Lutheran Mission Cooperation and Church Building in Thailand 1976-1994. Åbo: Åbo akademis förlag.

Boon-Itt, Bantoon (2007). 'A Study of the Dialogue between Christianity and Theravada Buddhism in Thailand. As Represented by Buddhist and Christian Writings from Thailand in the period 1950-200o.' Doctor of Philosophy Dissertation, Department of Religious Studies, The Open University, St John's College.

Buddhadasa, Bhikkhu (1967). Christianity and Buddhism. Trans. by Venerable Punno, Mr. B. Siamwala, Mr. Hajji Prayoon Vadanyakul and an unknown person. Sinclaire Thompson Memorial Lecture, Fifth Series. Bangkok: Sublime Life Mission.

Chaiwan, Saad (1984). 'A Study of Christian Mission in Thailand.' East Asia Journal of Theology 2,1: 62-74.

Clarke, Sathianathan (2014). 'World Christianity and Postcolonial Mission. A Path Forward for the Twenty-first Century.' Theology Today 71,2: 192-206.

Clooney, Francis X. SJ (2005). Divine Mother, Blessed Mother. Hindu Goddesses and the Virgin Mary. Oxford: Oxford University Press.

Clooney, Francis X. SJ (2010a). Comparative Theology. Deep Learning Across Religious Borders. Malden, MA: Wiley-Blackwell.

Clooney, Francis X. SJ, ed. (2010b). The New Comparative Theology. Interreligious Insights from the Next Generation. New York, NY: T\&T Clark.

Cohen, Erik (1995). 'Christianization and Indigenization. Contrasting Processes of Religious Adaption in Thailand.' In Steven Kaplan, ed. Indigenous Responses to Western Christianity. New York: New York University Press: 29-55.

Davis, John R. (1993). Poles Apart? Contextualizing the Gospel. Bangkok: Kanok Bannasan. 
Fleming, Kenneth (2002). Asian Christian Theologians in Dialogue with Buddhism. Oxford: Peter Lang.

Fleming, Kenneth (2014). Buddhist-Christian Encounter in Contemporary Thailand. Frankfurt am Main: Peter Lang.

Fredericks, James L. (2004). Buddhists and Christians: Through Comparative Theology to Solidarity. Maryknoll, NY: Orbis Books.

Galgao, Gabby Jed C. (2019). 'Factors Contributing to Thai Buddhists' Adoption of Adventist Beliefs-Part 1.' Human Behavior, Development and Society 20,2: 50-61.

Grether, Herbert G. (1960). 'The Cross and the Bodhi Tree.' Theology Today XVI,4: $446-458$.

Haug, Kari Storstein (2012). Interpreting Proverbs 11:18-31, Psalm 73, and Ecclesiastes 9:1-12 in Light of, and as a Response to, Thai Buddhist Interpretations. A Contribution to Christian-Buddhist Dialogue. Leiden and Boston: Brill.

Haug, Kari Storstein (2015). 'Cultural Affirmation or Innovation? Christian Spirituality in Its Thai Cultural Context.' In Knut Alfsvåg and Thor Strandenæs, eds. Urban Christian Spirituality. East Asian and Nordic Perspectives. Frankfurt am Main: Peter Lang: 83-101.

Heim, S. Mark (2019). 'Comparative Theology at Twenty-Five: The End of the Beginning.' Modern Theology 35,1: 163-180.

Hilderbrand, Kelly Michael (2016). 'What Led Thai Buddhist Background Believers to Become Christians. A Study of One Church in Bangkok.' Missiology. An International Review 44,4: 400-415.

Hong-Shik, Shin (1989). Principles of Church Planting as Illustrated in Thai Theravada Context. Bangkok: Kanok Bannasan.

Hovemyr, Anders (1983). 'Towards a Theology of the Incarnation in the Thai Context.' The East Asia Journal of Theology 1,2: 78-83.

Hughes, Philip J. (1982). 'Christianity and Culture. A Case Study in Northern Thailand.' Ph.D thesis, South East Asia Graduate School of Theology.

Hughes, Philip J (1984). 'The Assimilation of Christianity in the Thai Culture.' Religion 14: $313-336$.

Hughes, Philip J. (1985). 'Christianity and Buddhism in Thailand.' Journal of the Siam Society 73,1-2: 23-41.

Ishii, Yoneo (1986). Sangha, State and Society. Thai Buddhism in History. Trans. by Peter Hawkes. Honolulu: The University of Hawaii Press.

Keyes, Charles F. (1993). 'Why the Thai are not Christians. Buddhist and Christian Conversion in Thailand.' In Robert W. Hefner, ed. Conversion to Christianity. Historical and Anthropological Perspectives on a Great Transformation. Berkeley, CA: University of California Press: 259-284.

Kitiarsa, Pattana (2012). Medium, Monks, and Amulets. Thai Popular Buddhism Today. Chiang Mai: Silkworm Books. 
Koyama, Kosuke (1974). Waterbuffalo Theology. London: Sсм Press Ltd.

Kusawadee, Banjob (2010). Suffering and the Cross. The Meaning of the Theology of the Cross for a Thai Christian Understanding of Suffering. Bangkok: Luther Seminary in Thailand.

Lertjitlekha, Cherdchai (1998). Buddhist Pañña. A Study of Theravada Buddhist Ethics in Dialogue with Christian morality. Bangkok: Saengtham College Press.

Lorgunpai, Seree (1994). 'The Books of Ecclesiastes and Thai Buddhism.' The Asia Journal of Theology 8,1: 155-162.

Lorgunpai, Seree (1995). 'World Lover, World Leaver. The Book of Ecclesiastes and Thai Buddhism.' Doctor of Philosophy Dissertation, The Faculty of Divinity, New College, University of Edinburgh.

Mejudhon, Nantachai (1997). 'Meekness. A New Approach to Christian Witness to the Thai people.' Doctor of Missiology Dissertation, Faculty of the E. Stanley Jones School of World Mission and Evangelism, Asbury Theological Seminary.

Mejudhon, Ubolwan (1997). 'The Way of Meekness. Being Thai and Christian in the Thai Way.' Doctor of Missiology, Asbury Theological Seminary.

National Statistical Office. Report on Population Characteristics. The 2015-2016 Survey of Population Change. http://web.nso.go.th/en/survey/popchan/pop_change-Report. htm. Accessed 18-06-2020.

Payutto, Phra Prayudh. (2003/2546) (In Thai). Buddhadhamma. Revised and Expanded Version. Bangkok: Mahachulalongkornrajavidyalaya University.

Phra, Dhammapitaka/P.A. Payutto (2001). Thai Buddhism in the Buddhist World. A Survey of the Buddhist Situation Against a Historical Background. Bangkok: Buddhadhamma Foundation.

Petchsongkram, Wan(1975). Talkin the Shade of the Bo Tree. Trans. by Frances E. Hudgins. Bangkok: Thai Gospel Press.

Phongpit, Michael Seri (1978). 'The Problem of Religious Language. A Study of Buddhadasa Bhikkhu and Ian Ramsey as Models for a Mutual Understanding of Buddhism and Christianity.' PhD thesis. Münich.

Phongpit, Seri (1990/2533). 'Buddhist-Christian Approach to Social Liberation.' In Sulak Sivaraska, ed. Radical Conservatism. Buddhism in the Contemporary World. Articles in Honour of Bhikkhu Buddhadasa's 84th Birthday Anniversary. Bangkok: International Network of Engaged Buddhism: 459-468.

Podhisita, Chai (1998/2541). 'Buddhism and Thai World View.' In Amara Pongsapich, ed. Traditional and Changing Thai World View. Bangkok: Chulalongkorn University Press: $3^{1-62 .}$

O'Donnell, Emma (2017). 'Methodological Considerations on the Role of Experience in Comparative Theology.' In Francis X. Clooney and Klaus von Stosch, eds. How To Do Comparative Theology. New York: Fordham University Press: 259-270. 
Rapley, Tim (2004). 'Interviews.' In Clive Seale, Giampietro Gobo, Jaber F Gubrium and David Silverman, eds. Qualitative Research Practice. London: Sage: 15-33.

Ratanakul, Pinit (2005). 'Interfaith Dialogue. A Thai Buddhist Perspective.' In Ronald Y. Nakasone, ed. The Transforming Spiritual Landscape. Buddhist-Christian Encounters. Fremont, CA: Dharma Cloud Publishers: 71-78.

Reynolds, Craig J., ed. (2002). National Identity and Its Defenders. Thailand Today. Chiang Mai: Silkworm Books.

Sandland, Morten.(2014).JoiningNew Congregations - Motives, Ways and Consequences. A Comparative Study of New Congregations in a Norwegian Folk Church Context and a Thai Minority Context. Frankfurt am Main: Peter Lang.

Sivaraksa, Sulak (1986). 'Christianity in the Reflection of Buddhism.' In Hans Küng, Jürgen Moltmann and Marcus Lefébure, eds. Christianity Among World Religions. Edinburgh: T.\&T. Clark LTD: 55-59.

Sivaraksa, Sulak (2002). 'What can Christians Contribute to an Understanding of Buddhism in Thailand?' Swedish Missiological Themes 9o,1: 85-91.

Slagter, Robert, and Harold R. Kerbo (200o). Modern Thailand. Boston, MA: McGrawHill Higher Education.

Smith, Alex G. (1999). Siamese Gold. A History of Church Growth in Thailand. An Interpretive Analysis. Bangkok: Kanok Bannasan.

Spiro, Melford E. (1982). Buddhism and Society. A Great Tradition and its Burmese Vicissitudes. Berkeley, CA: University of California Press.

Suwanbubbha, Parichart (1994). 'Grace and Kamma. A Case Study of Religio-Cultural Encounters in Protestant and Buddhist Communities in Bangkok and Its Relevant Environs, Thailand.' Doctor of Theology Dissertation, The Lutheran School of Theology at Chicago.

Suwanbubbha, Parichart (1998). 'Can Theravada Buddhist Ethics Solve Economic Problems? The Example of Thailand.' In Viggo Mortensen, ed. A Just Asia. The Challenge of a Globalized Economy. Geneva: Lutheran World Federation: 113-123.

Swanson, Herbert R. (1984). Khrischak Muang Nua. A Study in Northern Thai Church History. Bangkok: Chuan Printing Press.

Swanson, Herbert R. (2002). 'Dancing to the Temple, Dancing to the Church. Reflections on Thai Theology.' Journal of Theologies and Cultures in Asia 1: 59-78.

Swearer, Donald K. (1973). 'Thai Buddhism. Two Responses to Modernity' In Bardwell L. Smith, ed. Tradition and Change in Theravada Buddhism. Essays on Ceylon and Thailand in the 19th and 2oth Centuries. Leiden: Brill: 78-93.

Tanner, Kathryn (1997). Theories of Culture. A New Agenda for Theology. Guides to Theological Inquiry. Minneapolis: Fortress Press.

Tatari, Muna (2017). 'Using Contemparary Insights in Developing Kalām. A Personal Reflection on Being Trained in Comparative Theology.' In Francis X. Clooney 
and Klaus von Stosch, eds. How To Do Comparative Theology. New York: Fordham University Press: 188-205.

Taylor, Steve (2001). 'Gaps in Beliefs of Thai Christians.' Evangelical Missions Quarterly 37,1: $72-81$.

Taylor, Steve (2005). 'A Prologomena for the Thai Context. A Starting Point for Thai Theology.' Evangelical Review of Theology 29,1: 32-51.

Vanhoozer, Kevin J., Charles A. Anderson and Michael J. Sleasman, eds. (2007). Everyday Theology. How to Read Cultural Texts and Interpret Trends. Grand Rapids: Baker Academic.

Visser, Marten (2009). Conversion Growth of Protestant Churches in Thailand. Boekencentrum.

Wigg-Stevenson, Natalie (2014). Ethnographic Theology. An Inquiry into the Production of Theological Knowledge. Palgrave Macmillan.

Zehner, Edwin (1991). 'Merit, Man and Ministry. Traditional Thai Hierarchies in a Contemporary Church.' Social Compass 38:2: 155-175.

Zehner, Edwin (2005). 'Orthodox Hybridities. Anti-Syncretism and Localization in the Evangelical Christianity of Thailand.' Anthropological Quarterly 78,3:585-617.

Zehner, Edwin (2009). 'Beyond Anti-syncretism: Gospel, Context and Authority in the New Testament and in Thai Conversions to Christianity.' In Brian M. Howell and Edwin Zehner, eds. Power and Identity in the Global Church. Six Contemporary Cases. Pasadena, California: William Carey Library: 155-183.

Zehner, Edwin (2013). 'Conversion to Christianity among the Thai and Sino-Thai of Modern Thailand: Growth, Experimentation, and Networking in the Contemporary Context.' In Jonathan A. Seitz and Richard Fox Young, eds. Asia in the Making of Christianity. Conversion, Agency, and Indigeneity, 1600 to the Present. Leiden: Brill: 403-426. 